With this type of vehicle, air-operated doors can be provided, and these seem essential for a heavy suburban service.

\title{
Wagon Stock.
}

From an engineering point of view, the British Railways are archaic as regards the ordinary wagon stock used. 8-ton, 10-ton, 12-ton, 16-ton, and 20-ton four-wheel wagons with three-link couplings limit the speed of goods trains to an average of about 25 miles per hour and, as practically no wagons have power brakes, the trains are limited to the load the engine with its brakes can stop (Figs. 13, 14, 15, Plate 2).

These factors reduce the capacity of the line and increase the cost of transport. Unfortunately, during the life of the railways the business has become more and more a retail one, and the traders of the country have been taught that they can expect their goods in penny numbers so that they need not make any provision for warehousing.

Even the British coal business, up to the war, has been split up into hundreds of concerns, each dealing with several collieries and each requiring its supplies in preferably 8-ton lots.

In America coal is graded by size and supply in 60-ton and 80-ton hopper wagons in bulk, and these wagons are run on to an elevated stage and discharged into a bin from which the coal gravitates into the road vehicles for distribution.

Until the whole problem of freight distribution is tackled so that goods can be handled in bulk, it seems impossible to depart from the small wagon, and until that is done the introduction of power brakes for goods trains and improved coupling arrangements will be held up.

The Paper is accompanied by 13 diagrams and 2 photographs, from which the half-tone page Plates and the folding Plates, have been prepared.

\section{Discussion.}

The Author introduced the Paper with the aid of lantern slides.

The Chairman said he was sure all the members present would agree with him that the Author had given them a vast field to discuss; he had covered nearly everything that could be covered in connexion with rolling stock and had put forward problems which should keep those who were interested in the design of stock thinking for the next five or ten years. The experience which the Author had had was extremely valuable in connexion with the Paper, because when he wrote about American stock 

1. (1) H 然 - 14 : (1)

H.

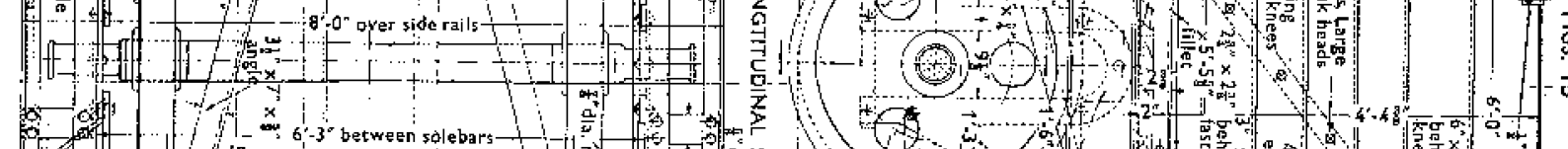
H. II

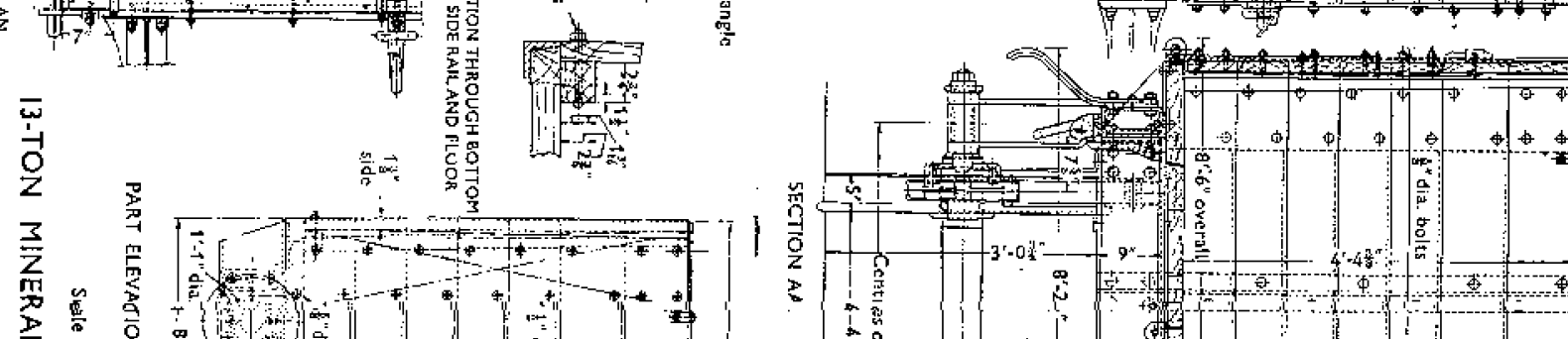
3 H I I $\rightarrow$ हn

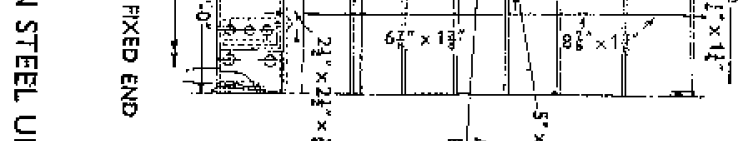

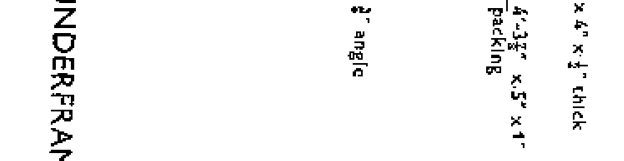

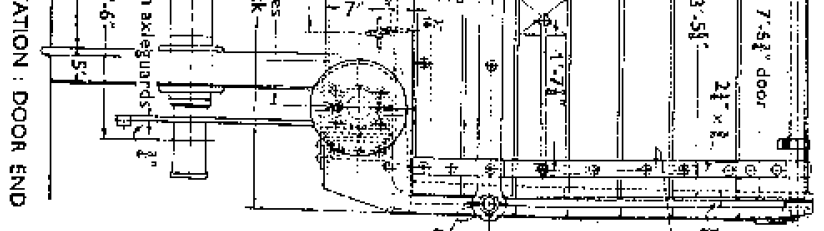
min

he was writing about something which he had actually seen. The members of the Division were extremely indebted to the Author for preparing the Paper.

Mr. A. N. Moon said that the Author had mentioned one of the most important aspects of rolling stock design when he referred to the reduction of weight.

From the point of view of the intending traveller and the intending consignor of goods, a still more fundamentally important subject was that of cost. For the ordinary member of the travelling public, the question of the cost of the journey was a high priority, then comfort, speed, safety, and then additional amenities to increase the comfort of the journey. In the case of freight traffic, the priority from the point of view of the consignor of goods would probably be cost, then safety, and then speed.

Cost, so far as rolling stock design was concerned, was affected in two ways ; by the capital and maintenance costs of the vehicle and the cost of its haulage. It was, of course, in the latter that weight reduction became so important. From about 1923, the time of the amalgamations, every effort had been made to reduce the capital cost of vehicles; that had been done partly by standardization and semi-mass-production methods, and partly by the elimination of all unnecessary operations in manufacture. As a result, the tendency had been for the weight of the stock to increase. For instance, on the L.M.S. Railway in 1923 a thirdclass vestibule car, 57 feet long, carrying 56 passengers, weighed on the average about 28 tons, whereas in 1935 a similar vehicle, carrying the same number of passengers, weighed about 30 tons. The increase had been largely due to the desire to reduce unnecessary operations and to reduce maintenance costs. It had become clear that some attention must be given to the question of reducing the weight, so as to counterbalance any tendency to increased weight arising from the increase of amenities and comfort.

The methods adopted to reduce weight had been, firstly, the introduction of modern methods of fabrication; secondly, closer attention to design, with a view to the elimination of unnecessary material; and thirdly, the use of new materials. Modern methods of fabrication included the introduction of arc welding into the fabrication of the steel frame in 1934.

The designer had to bear in mind that he had to produce something which was not too costly, whilst endeavouring to effect a reduction in weight. It would be very interesting to try to reduce the weight to the minimum by the elimination of all unnecessary material, but Mr. Moon feared that it would be found that the cost of fabricating a frame in that way would be too great for it to be worth while, except possibly in the case of certain special vehicles.

As to new materials, the Author had mentioned light alloys, but Mr. Moon feared that the cost of light alloys at present was such as to render them impracticable for use in frame construction or anything of that kind. 
In discussing future prospects the Author had referred to the possibility of the design and manufacture of steel stock. There was much to be said for that, in view of the present shortage of timber and the fact that steel was a home product which did not require seasoning, and a good deal of experience had been obtained in its manufacture.

Mr. E. A. W. Turbett said that it might be inadvisable to lighten rolling stock too much. That was a point that should be considered. There were certainly a number of materials available at the present moment, but they were largely unproved.

With regard to the cleanliness of coaches, the various steps mentioned in the Paper could be taken, but they tended to increase the cost, and at present cost was as important as it had ever been.

He thought a great deal could be done to make the seats more comfortable. He agreed with the Author that the ideas of different people with regard to the comfort of seats varied very greatly, but some of the air transport lines had a seat with a back which could be lifted up and down and which could be made to conform with nearly everybody's idea of comfort.

The Author had not referred to the interior lighting of the coach, which Mr. Turbett thought was almost as important as the comfort of the seats. It was a very contentious matter and gave rise to much difference of opinion, and it was difficult to ascertain which type of lighting would be most popular.

Mr. Gilbert Matthews said that there were two questions with which he had hoped the Author would deal. One was the subject of roller bearings and why British railways had not adopted them when so many other countries used them, apparently with good results. The other question was that of more effective braking, which would be a very considerable help.

With regard to the reduction of weight, by welded construction 5 tons per coach could be saved, which, on a 12-coach train, was equivalent to about 2 coaches. That was of very considerable assistance to the traffic department.

Mr. Rolt Hammond observed that Fig. 16 showed a map of the Britishowned Argentine railways, superimposed on a map of north-western Europe. It indicated the extensive area covered by the railways, which were a wonderful example of British enterprise in foreign countries. The Argentine grain belt was three times the size of Great Britain, a fact which gave some idea of the traffic handled on the railways in grain alone. There was a grain elevator at Bahia Blanca, on the Buenos Aires Great Southern Railway, with a capacity of 80,000 tons. Six ships could be loaded there at the rate of 1,000 tons per hour per ship.

Fig. 17 showed a first-class coach on the Central Argentine Railway. It was made of steel with wood lining, weighed 43 tons, carried 80 passengers, and was provided with three lavatories, electric lighting, ventilating, 
Fig. 16.

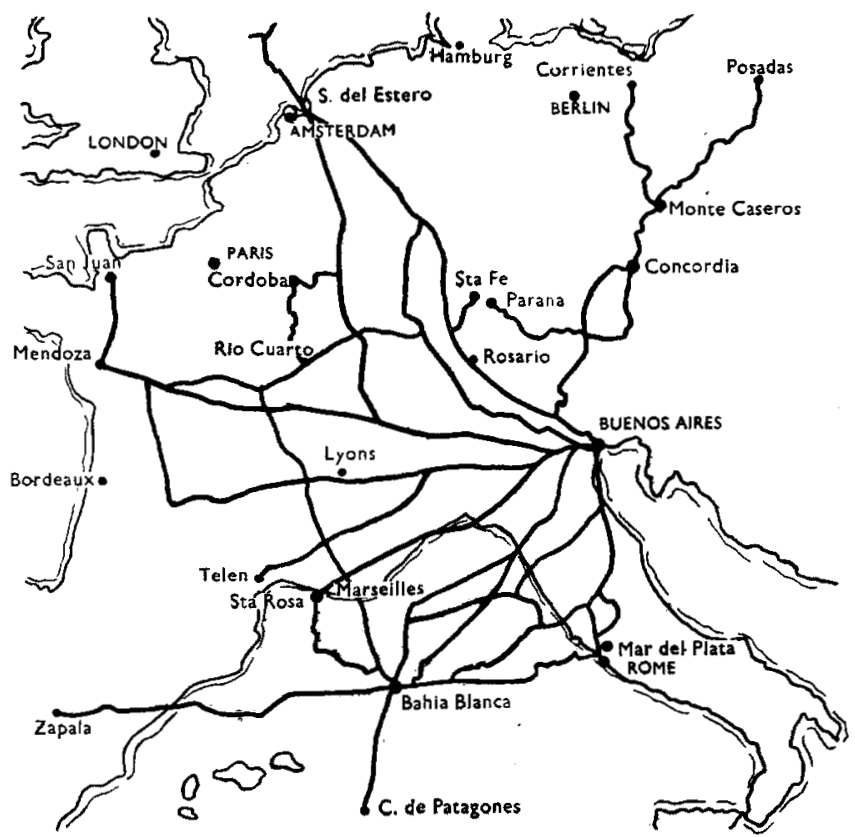

Fig. 17.

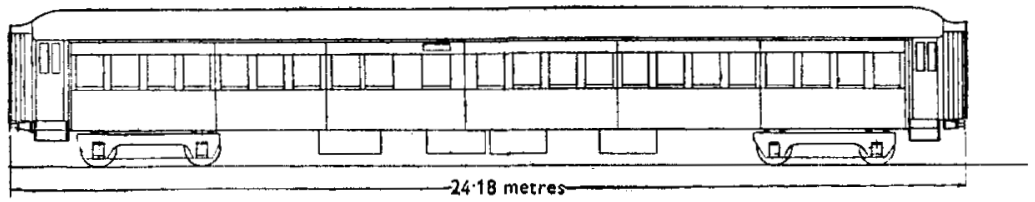


and steam heating. Ventilation was very important in the Argentine, as there was an enormous amount of dust there.

Mr. Hammond had been very interested in the question of weight reduction, to which the Author had referred. A few years ago a unit had been built for the Chemin de Fer du Nord. It was a three-coach articulated unit with a mild-steel underframe and a magnesium-aluminium-alloy coach portion. The combination of arc welding and the use of a light alloy for the body of the coach made, he thought, a very satisfactory unit.

He considered that welding was the only really scientific way of making a joint, but its full value could be obtained only if there was strict adherence to welding procedure.

Mr. I. Lynes was interested in the section on main-line vehicles and the description given there of the building of lightweight steel stock. The orthodox construction of vehicles in Great Britain comprised steel underframes and bogies with timber bodies, the new development being that the underframe and body were made integral, and, instead of dealing with a body which was unstressed, in the case of the lightweight bodies stressed bodies were dealt with.

Originally the steel stock had been very heavy and robust, plates of considerable thickness having been used, and there had been an attempt to whittle the weight down, but, as time went on, deterioration of the steel set in unless it could be arrested, and that was still a problem for the coachbuilder. There was the possibility of the factors of safety, worked out on the drawing-board, steadily diminishing and bodies having to be replaced much earlier owing to their inability to stand safely the traffic conditions: The problem was one which should not be overlooked by designers and people who maintained stock. Further, it would be very interesting to know how the life of the stressed vehicles compared with that of the unstressed timber bodies which it was known had lasted for fifty years or longer.

It was true, as the Author had said, that two railways in Great Britain used central couplers on their coaches and two used only side buffers and screw couplings. Mr. Lynes thought that the Author might have given the railways a lead in the matter, but he had left them to solve the problem for themselves. From the point of view of mechanical merits, the autocoupler was the better of the two devices. The operating department were not confident that the auto-coupler was the better of the two, and that lack of confidence might be one of the reasons why the auto-coupler had not been adopted on all the railways in Great Britain. The two railways that had adopted it had surmounted whatever difficulties there might be in connexion with its use and were continuing to surmount them. As far as cost and weight were concerned, there was very little difference in the two methods. The question was simply one of performance, and when it had been called upon to do a serious job, as in collisions, auto-coupling had been proved to be definitely advantageous. The problem might have been 
simplified if, coincident with the fitting of auto-couplers to rolling stock, mechanical engineers had had sufficient faith to fit their engines and tenders with auto-couplers. The changing over, if it was considered desirable, would be very much easier if the engines could hang on to and pull away trains whether they were auto-coupled stock or had side buffers. The factor which prevented the general adoption of auto-couplers was the cost of fitting coaches with both the side buffer and auto-coupling arrangements.

The Author had not referred to the van stock, which, though rather a despised part of the rolling stock, was actually a source of a great deal of revenue. It was the Carter Paterson business of the railway companies and was therefore worth consideration. Mr. Bulleid, the Chief Mechanical Engineer of the Southern Railway, had brought out in the last few years ten 4-wheeled plastic-panelled vans. The bodies of those vans were of extremely light construction, and could drift fore and aft under shock conditions to the extent of about 1 foot either way, which safeguarded the lightness of the structure. They were standing up to their service so well that they were considered fit to run in the Continental services associated with the Golden Arrow trains. The effect of that experiment, which was a bold one, had been to reduce the tare weight of the vehicle from 13 tous to 10 tons $4 \mathrm{cwt}$., a saving of 20 per cent. Another point of interest was that the vans were running on wagon wheels 3 feet $1 \frac{1}{2}$ inches in diameter, whereas the usual carriage wheels in Great Britain had a diameter of 3 feet 6 inches. That reduction in diameter gave a saving of weight of about $8 \mathrm{cwt}$., which, on wheels alone, seemed to be really worth while. In America the wheels were smaller than in Britain, as the Author knew, and he could not see why smaller wheels could not be adopted in Great Britain, with a reduction in the dead weight, without going too far in lightweight design.

After referring to the saving of $£ 10$ per annum on electric current for every ton that could be saved on the rolling stock, the Author said that. was in addition to "any advantage to be gained on wear and tear and track, etc." As he had submitted before, the track was really the most. important part of the railway, and he would have liked to see some figures from Mr. Wallace with regard to what could be saved on every ton of rolling stock saved.

Mr. H: A. Alexander did not share the Author's opinion about the American saloon cars. He thought they were particularly comfortable; each passenger had an armchair to himself, which he could rotate so that he could look in any direction. They had the disadvantage, as compared. with British coaches, that people were not allowed to smoke in them.

The Author had referred to the archaic wagons, from 8 tons to 20 tons, on the British railways, and he gathered that the Author blamed the trader and the coal factor for them, but the Author would remember that when he was in the service of the Great Western Railway some years ago the question of the use of larger wagons was investigated and it was found that it 
was not the trader or the coal factor, but the works and their lay-out that made it impossible to use larger wagons. In the virgin countries of America, of course, there was nothing to prevent the use of enormous wagons, and very fine ones were used.

Mr. J. S. Tritton said his firm had been engaged for the last five or six months in the designing of lightweight suburban rolling stock for the electric suburban system in India. The genesis of that work was interesting. Their client was prepared to accept aircraft design and various modern features which were unorthodox.

The design had not turned out as expected. It was hoped to be able to design a geodetic structure for the body, something like an aircraft fuselage, with recesses underneath in which small light bogies could be run, but when aircraft design, as applied to railway practice, had been investigated, it was found that the aircraft construction demanded a very large number of small pressings which made design difficult in the way of doors, windows, and other apertures which had to be made in the sides of a coach. It was not possible to persuade the aircraft manufacturers to produce the panels in a sufficiently great width and length for a 65 -foot or a 70-foot coach. Therefore his firm had had to return reluctantly to more orthodox design for railway work, and the eventual design had proved to be a high-tensile steel underframe with a light-weight aluminiumor magnesium-alloy superstructure. The superstructure was designed partially on the Viereendeel truss form to take part of the stresses, but the underframe was made self-contained as regards its stresses, and the additional strength given by the stresses in the superstructure was thrown in gratis as an extra factor of safety.

Mr. Tritton thought the Author might have brought out the point that saving in weight was more profitable in goods or freight stock than it was in passenger stock. If 2 or 3 tons could be saved in the tare weight of a freight wagon, that enabled 2 or 3 tons extra load to be carried for a given axle load, but that unfortunately did not hold good in the case of passenger stock, because, as a rule, passenger stock was designed for a given super-surface per passenger and passengers could not be loaded one on top of the other in orthodox design; therefore the floor-area was limited and the saving in weight could not give an increase in load.

The Author had made an important comment on the necessity of avoiding corrosion in lightweight sections. In the design for the suburban rolling stock in India, Mr. Tritton's firm had been able to justify the extra cost of the lightweight alloy superstructure by the anticipated saving in maintenance alone, quite apart from the anticipated saving in the current used for hauling and accelerating the coaches.

** Mr. R. L. McIlmoyle observed that designers of rolling stock appeared to be more conservative than those in any other branch of

*** This communication was submitted in writing.-SEC. I.C.E. 
engineering. The practice of providing an underframe capable of carrying the whole load was unduly extravagant in material as, in practice, the body had to carry quite a proportion of the weight. No matter how stiff the underframe was, it deflected under load and whether the body was rigidly attached to or merely rested on the underframe, it would follow the underframe when it deflected and, in doing so, took over a portion of the load.

Mr. Tritton had stated that, in the new coaches he had designed, the underframe was made sufficiently strong to carry the whole of the load, whilst the strength of the body was provided as an additional factor of safety. That was not quite correct; the strength of the vehicle would be either somewhat less or somewhat more than the sum of the strengths of the two parts, depending on the stiffness of the connexions and the relative moments of inertia of the components. As the body had to carry part of the load, it seemed, therefore, uneconomical to design the underframe on the basis that such relief did not exist.

Mr. McIlmoyle suggested that designers of rolling stock could obtain much valuable information from the study of the practice of Structural Engineers, both in application of design and welding. In the latter, particularly, attention should be directed to the methods employed to obtain welded rigid joints in structural work. That would enable much of the bracing at present used on welded underframes to be eliminated, with a very appreciable reduction in total weight. An examination of the details of the welded underframes shown indicated that, in general, riveted practice, so far as bracing, etc., was concerned had been followed, the only alteration being that welding had been substituted for rivets as a fastening material. A surprising amount of weight could be eliminated if attention were given to the question of detail design.

The Author, in reply, said that Mr. Moon had rightly referred to the cost as being an important factor when dealing with new vehicles, and Mr. Lynes had spoken about the additional cost of developing lightweight stock. The type of construction in the case of lightweight stock was a new one ; it was different from that which the works normally carried out and it involved putting down plant and tools and making jigs, with a fairly considerable capital outlay. The L.M.S. Railway were fortunate, when they built the lightweight stock for the Liverpool-Southport line, to be given instructions to renew twenty-one complete trains, as that spread the cost over a fairly large order, and it was hoped that many of the tools which were developed for building that stock could be used for building new lightweight main-line stock.

Mr. Moon had referred to speed, safety, comfort, and other amenities, and it was true that all those matters had to be considered. Mr. Turbett had mentioned the comfortable seats with adjustable backs on some of the air lines. He himself had been impressed when he had travelled by aeroplane by the ease with which the angle of the back of the seats could be regulated and by the way in which the seat conformed with one's body 
in some of the modern aeroplanes. He thought that carriage designers should take that form of seat into consideration for some of the new lightweight stock that was being developed.

Mr. Gilbert Matthews had referred to the fact that roller bearings had not been mentioned in the Paper. The Author did not know whether the Great Western. Railway were having any trouble with the bearings which they had at present, but that had not been the case when he was there. What advantage did Mr. Matthews think would be obtained from the use of roller bearings? Personally he preferred to run on oil and not on steel, but he was quite prepared to revise his opinion if he saw some justification for so doing. The main weakness of the existing bearing was the small collar that took the end wear. That difficulty had been overcome on the L.P.T.B. stock and on the Liverpool-Southport stock by eliminating the collar at the end of the axle, and using a hard bronze pad which had a bearing on the end of the axle and was fitted with a felt lubricator for taking the end thrust. He believed that was a very useful form of construction, even with roller bearings, for taking the end thrust, and on the new lightweight stock, provided there was a certain cushion arrangement incorporated with the pad, it seemed to him to reduce the need for roller bearings considerably, with a great advantage and saving in cost.

With regard to effective braking, he supposed that Mr. Matthews meant effective braking of carriage stock. He did not know that any trouble was being experienced in that direction. If a train going at 80 miles per hour was stopped in 100 yards, that might be good braking, but it would be very bad driving and he thought, rather an impossibility. Emergency stopping was not altogether comfortable.

As to the speed of freight trains, he had stated in the Paper that the average speed was 25 miles per hour. He was aware of the fact that freight trains ran at much faster speeds between certain points.

He had been interested to see the developments on the Argentine railways which had been shown by Mr. Hammond and to hear of the weight reduction in their three-coach articulated set. With their long distances, it must be a great advantage to the operating department to have the stock which they now possessed.

Mr. Lynes had said that auto-couplers had mechanical merits, but personally he would rather refer to brute force. He had never seen an auto-coupler which gave a good cushioning effect. His experience in America had been very unfortunate; when passenger trains had to start like goods trains it was not very comfortable for the passengers.

He thought that when Mr. Alexander was in America he must have had the privilege of riding in drawing-room cars, which were provided with comfortable easy-chairs. The comparison in the Paper was made with what the Americans called the day coach, which was the democratic coach which the Americans said everyone used, but those who could afford it travelled in the drawing-room cars. The Americans had only one class 
on their railways, but they had a drawing-room car for which passengers had to pay extra.

Mr. Tritton's information about the lightweight stock for India was very interesting. He could quite understand that it had been necessary to depart from aircraft design, but he was sure that the efforts which Mr. Tritton was making to provide lightweight stock would be watehed with much interest by all the railways.

The Chairman said that the present meeting was the last meeting of the Railway Engineering Division for Session 1945-46, and it also marked the termination of his period of office. He wished to say how pleased he had been at the good attendances at the meetings of the Division and what an honour and pleasure it had been to him to preside during the past three years. 